УДК 75(=161.1)(09)

ББК $85.143(2=411.2) 6$

DOI 10.25281/2072-3156-2018-15-2-214-221

В.Ф. КАПИЦА

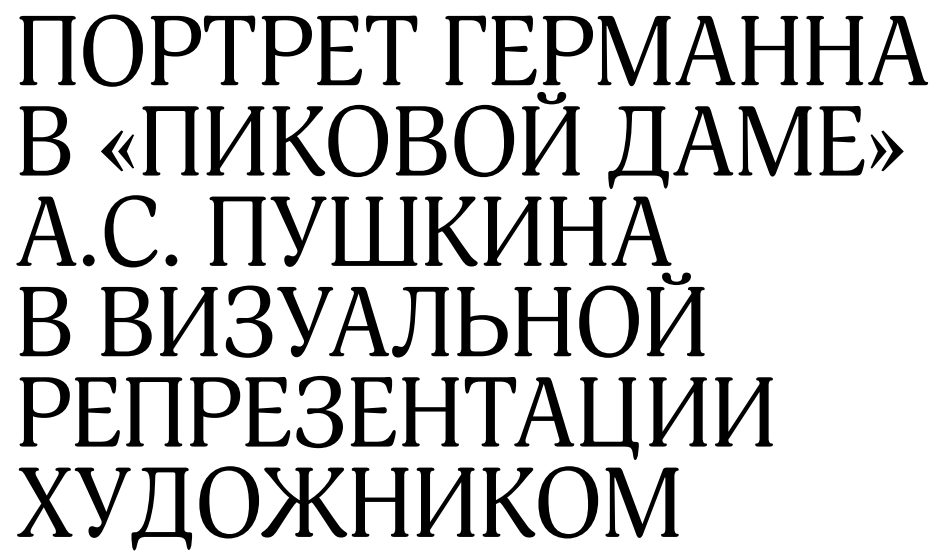

\author{
Вера Федоровна Капица, \\ Институт мировой литературы им. А.М. Горького, \\ отдел рукописей, \\ научный сотрудник \\ Поварская ул., д. 25а, Москва, 121069, Россия \\ E-mail: kapicavera@mail.ru
}

Реферат. В среде русской эмиграции 1920-1930-х г2. образовалось особое сообщество представителей художественного мира, поддерживающих тендениию сохранения отечественной культуры и вместе с тем стремившихся вписать ее в мировой контекст, учитывая творческие поиски, которые велись в то время. Один из таких представителей эмиграции живописеи, график, сиенограф В.И. Шухаев (18871973). Именно во Франиии развернулась его деятельность как автора книг художника, воспринимаемых в качестве особого произведения искусства, в котором значимы все элементы книги. Две значительные работы В.И. Шухаева в области книжной графики связаны с именем А.С. Пушкина: иллюстрации и оформление к повести «Пиковая дама» и трагедии «Борис Годунов».

В качестве материала для исследования в настоящей статье использовано франиузское издание 1923 г. «Пиковой дамы» А.С. Пушкина. Этот выбор обусловлен тем, что В.И. Шухаевым не только выполнены иллюстрации, но также представлено своеобразное видение произведения, он самобытно проясняет и конкретизирует отдельные особенности сюжетного построения повести свойственным ему художественным языком.
Предмет конкретного изучения - своеобразие видения В.И. Шухаевым главного персонажа произведения - Германна, особенности его портретной характеристики и приемы ее организации. Последовательное прочтение произведения, несомненно, отразилось в иллюстративном пространстве повести. Художник практически создает свой вариант видения текста, акиентируя внимание на драматической составляющей произведения. Он использует визуальность изображения А.С. Пушкина, чтобы вывести свою читательскую кониепцию прочтения «Пиковой дамы». Показаны основные приемы работы художника, проявившего себя продолжателем традиций и новатором.

Как иллюстратор В.И. Шухаев не только выдержал конкуреничю с франиузскими художниками, но и внес собственные находки: предложил приничи монтажа в графике, разработал новую методику рисунков тушью, создал единый художественный комплекс книги от обложки до последней конц,вки. В.И. Шухаев доказал, что оформление, полностью адекватное авторскому замыслу, возможно лишь при условии, что художник создает все части образа книги, подчиняя их единой творческой кониепиии.

Ключевые слова: русская эмиграция, книга художника, А.С. Пушкин, В.И. Шухаев, герой, визуальная репрезентация.

Для цитирования: Капийа В.Ф. Портрет Германна в «Пиковой даме» А.С. Пушкина в визуальной репрезентации художником // Обсерватория культуры. 2018. Т. 15, № 2. C. 214-221. DOI: 10.25281/2072-3156-2018-15-2-214-221. 


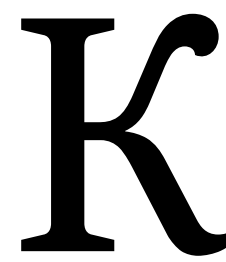

ультура русской эмиграции 19201930-х гг. представляла собой уникальное явление. Образовалось особое сообщество, в котором можно было увидеть практически всех представителей художественного мира: писателей, живописцев, артистов. Стремясь сберечь свою самобытность, эмиграция хотела сохранить национальную специфику, познакомить европейскую общественность с практически не известным ей искусством. Особую роль в процессе репрезентации сыграли художники русской эмиграции, поддерживающие тенденцию сохранения отечественной культуры и вместе с тем стремившиеся вписать ее в мировой контекст, учитывая творческие поиски, которые велись в то время.

\section{КНИГА ХУДОЖНИКА}

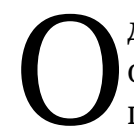
дним из таких представителей эмиграции оказался В.И. Шухаев (1887-1973) - живописец, график, сценограф, чья деятельность как автора книг художника развернулась именно во Франции. В настоящее время отсутствуют специальные работы, посвященные этой стороне его деятельности, хотя искусствоведческий и исторический анализ книг В.И. Шухаева содержится в публикациях И.Г. Мямлина [1], Н.А. Эйзабрашвили [2], М.В. Сеславинского [3].

Книга художника воспринимается нами как особое произведение искусства, в котором значимы все элементы книги ${ }^{1}$. Художник предстает не просто иллюстратором, а соавтором, проясняющим и дополняющим отдельными компонентами книги (страничными иллюстрациями, фронтисписом, виньетками) замысел автора произведения. В нашем случае книга художника выступает в качестве своеобразного информационного сообщения, адресованного иностранному читателю. В России были хорошо известны книжные опыты русских футуристов 1910-1920-х гг., прежде всего В. Каменского, они коррелировали с традицией французской livre d'artiste, также возникшей в начале XX века.

Творческие намерения русских художников поддерживались издательской деятельностью Ж. Шифрина, который привлек к работе над книжной иллюстрацией ведущие фигуры своего времени, организовав издательство «Плеяда». М. Сеславин-

\footnotetext{
${ }^{1}$ Приведем одну из точек зрения, согласно которой поддерживается особость данной формы: «Книга художника - это своеобразный творческий метод, в котором автор использует книжную форму в качестве основополагающего инструмента для самовыражения. Автор здесь - творец, мастер особого вида искусства в отличие от писателя, он создает книгу как целостный организм, в котором текст лишь одна из составляющих комплексного художественного высказывания» [4, с. 118].
}

ский отмечает: «По приблизительным подсчетам около 150 творцов стали работать в области книжной графики, обеспечив взлет как тиражей, так и наименований французской иллюстрированной книги. Некоторые имена наших соотечественников у всех на слуху (Ю. Анненков, И. Билибин, А. Бенуа, Н. Гончарова, Б. Григорьев, Б. Зворыкин, М. Ларионов, К. Сомов, М. Шагал, В. Шухаев, А. Яковлев)» [3]. Некоторые авторы выполняли свои работы именно для издательства «Плеяда», среди них оказался и В.И. Шухаев [5].

Две значительные работы В.И. Шухаева в области книжной графики связаны с именем А.С. Пушкина. Это иллюстрации и оформление к повести «Пиковая дама» (1923) [6] и трагедии «Борис Годунов» (1925) [7]. Особенно интересна серия иллюстраций к повести «Пиковая дама», которая открывает ряд изданий произведений русских классиков, оформленных Шухаевым.

\section{«ПИКОВАЯ ДАМА» В ИЛЛЮСТРАЦИЯХ В.И. ШУХАЕВА}

B качестве материала для исследования в настоящей статье нами привлечено французское издание «Пиковой дамы» А.С. Пушкина [6]. Этот выбор обусловлен тем, что В.И. Шухаевым не только выполнены иллюстрации к изданию, но также представлено своеобразное видение произведения, он самобытно проясняет и конкретизирует отдельные особенности сюжетного построения повести свойственным ему художественным языком. Речь идет о визуальной (зрительной) репрезентации текста, которая в последнее время стала объектом исследовательской рефлексии [8].

Комплексный подход к произведению искусства свойственен культуре эпохи модернизма. Хотя Шухаев справедливо считал себя реалистом, все же в его творчестве отразилась тенденция функционирования различных синтетических форм, использование элементов разных стилевых систем. Д.С. Лихачёв подчеркивал необходимость целостного исследования художественного сознания эпохи [9], в тесной взаимосвязи литературы, живописи, музыки, архитектуры, декоративно-прикладного искусства, национального и интернационального, как это было в эпоху модернизма, когда как раз и начинало развиваться творчество Шухаева.

Подобная тенденция изучения текста сложилась в последнее время. Методика предусматривает не только исследование всех составляющих произведения с художественных позиций, анализа основных приемов, способствующих его восприятию как единого целого, но и изучение всего памятника, в том 
числе и с графической точки зрения, оформления обложки, специфики введения текстовых иллюстраций. Нами также учитывается мнение В. Кандинского, который ввел понятие «текст художника», значимого как со стороны словесной составляющей, так и визуального выражения, когда читателю предоставляется возможность «следить за жизнью особого мира, видеть его глазами, осязать его, слышать аромат и его неподражаемо тонкую и значительную речь» [5]. Таким образом художник становится своеобразным соавтором словесного текста.

Именно такую возможность и предоставляет анализируемое нами произведение. Предмет конкретного изучения в настоящей статье - своеобразие видения В.И. Шухаевым главного персонажа произведения - Германна, особенности

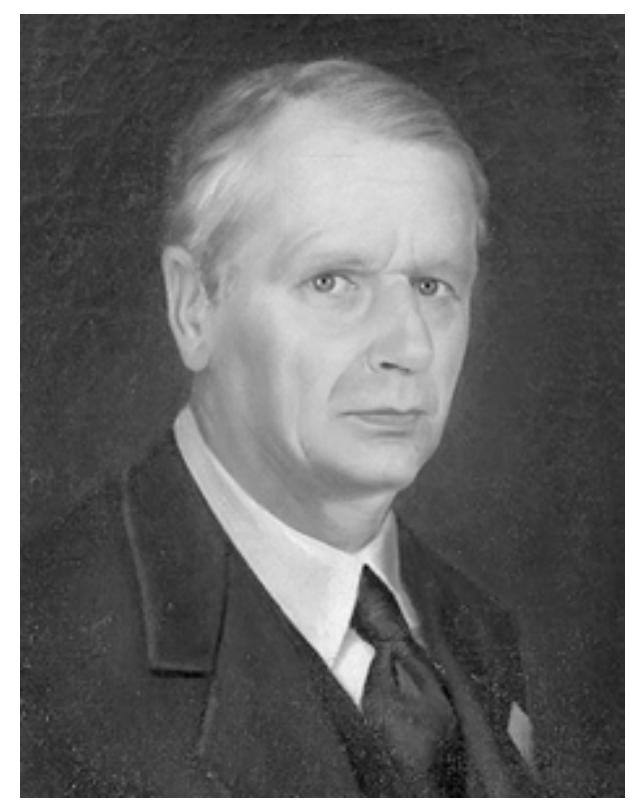

В.И. Шухаев. Автопортрет. 1945
Следующая иллюстрация в виде заставки зеркально повторяет текстовую иллюстрацию, на ней изображены игроки мужского пола. В соответствии с повествовательной наррацией выведено несколько центральных фигур («Однажды играли в карты у конногвардейца Нарумова»). Акцентировка вновь проводится традиционным для Шухаева способом, с помощью зеленого цвета.

На первых страницах повести во время вечеринки происходит представление героя, молодого инженера Германна. На иллюстрации изображены собравшиеся, кто из них Германн - неясно, но об этом можно догадаться по черному костюму «молодого инженера». Он контрастирует с сидящими напротив персонажами, выведенными соответственно более яркими цветами (белым и бордовым). Таким образом обозначаются будущие дейстего портретной характеристики и приемы ее организации. Хотя на обложке выведено имя другого героя - графини, именно с ним связана сюжетная основа произведения, которая и интересовала художника. Своеобразная интрига задается в текстовой иллюстрации, на которой изображены игроки разного пола, размещенная в центре рисунка дама задает тональность иллюстрации. «B то время дамы играли в фараон», - сообщает Пушкин. Известно, что сам поэт часто устраивал своеобразные сценки на полях своих рукописей, выставляя на них действующих лиц.

Похожее графическое решение находим у Шухаева. Подчеркивая театральность представления действующих лиц, он заставляет звучать в каждой страничной иллюстрации главным образом какойто один цвет. В первой сценке-иллюстрации выбран красный, в рисунке ко второй главе художником использован зеленый и лишь отчасти привлечен красный, в рисунках к главе третьей - белый, темные тона доминируют в четвертой и пятой главах, зеленый «возвращается» в шестой.

Проясняя свой замысел, Шухаев впоследствии говорил, что «намеренная лаконичность цвета соответствует строгому реалистическому стилю Пушкина» [10]. Поэтому он в основном использует контрастные цвета - белый и черный (вариантом является коричневый), тем самым подчеркивая драматизм коллизии. Вещественные и интерьерные детали (перья в прическах дам, канделябры на стенах) свидетельствуют о времени действия, вписываясь в повествовательное поле. вующие лица. Один из них, Томский, имеет особое значение в судьбе Германна, упоминание о нем начинает повесть («Не могу постигнуть, - продолжал Томский, - каким образом бабушка моя не понтирует!») и завершает повесть («Томский произведен в ротмистры и женится на княжне Полине»), косвенно ведущего сюжетную линию героя, поддерживающую кольцевую композицию.

Изображение персонажей условно и больше напоминает постановочную театральную картину, необходимую для создания уже реальной сцены, с четко продуманным расположением персонажей. Они обрисованы в единой тональности, что позволяет говорить о масочности изображения. Художник своеобразно вводит мотив игры, становящийся доминантным для мотивики повести: «Игра занимает меня сильно, - сказал Германн, - но я не в состоянии жертвовать необходимым в надежде приобрести излишнее».

Принцип троекратного повтора, позволяющий обозначить сходное изображение игроков, также использован в текстовой иллюстрации, предваряющей шестую главу. Теперь Германн стоит в полный рост перед пожилым господином, выведенным А.С. Пушкиным под именем Чекалинского: «Он был человек лет шестидесяти, самой почтенной наружности; голова покрыта была серебряной сединою; полное и свежее лицо изображало добродушие; глаза блистали, оживленные всегдашнею улыбкою».

Отсутствие персонификации в данной сцене позволяет автору вновь сосредоточиться на деталях, 
в центре оказывается зеленое сукно ломберного стола. В свете лампы видны только светлые лица, костюмы сливаются в единое черное пятно. Только две фигуры нарисованы детально - Чекалинский с застывшей улыбкой и стоящий спиной к нему Германн, одетый в темный мундир (предмет одежды выполняет атрибутивную функцию).

Гротескно-лаконичные изображения игроков позволяют говорить о том, что действующие лица снова обрисованы как маски и кажутся похожими друг на друга. Германн упирается в стол, тем самым делается акцент на руки, которым Шухаев придавал особенное значение в своих портретах. В данном случае важна и косвенная отсылка к повести: «Позвольте поставить карту, - сказал Германн, протягивая руку из-за толстого господина, тут же понтировавшего». Перечень действий вводит в ситуацию.

Изображение героя, своеобразный показ в составе других действующих лиц, соответствует опосредованной характеристике, данной Пушкиным Германну в лице Томского: «Германн немец: он расчетлив, вот и все!» Шухаев использует принцип скрытого портретного описания, поэтому и не показывает лицо героя в знаковой сцене.

В завершающей главу заставке также указывается на одежду героя, что превращает его в типичного представителя своего времени и среды. Своеобразным дополнением сказанному служит и концовка первой главы в виде трех фигур, одетых в соответствии с действием произведения. Длинные плащи, фуражки, цилиндры станут атрибутивными деталями, выход Германна от графини фиксируется в заставке в виде силуэта в одежде военного покроя. Подобная знаковость изображения характерна для Пушкина, стремящегося к выведению конкретных деталей. Постоянно поднятый воротник на иллюстрациях Шухаева превращается в атрибутивный признак.

Развитие характера происходит в повести постепенно. Вначале А.С. Пушкин говорит о «молодом инженере» и указывает на отдельные детали его внешности, состояние («быстрый румянец покрывал его бледные щеки всякий раз, когда взоры их встречались»), одежду (бобровый воротник, шляпа).

Похожую характеристику встречаем и в рисунке художника, стремящегося к детализации повествования. Доминирующая черная шляпа на белой стене позади героя подчеркивает его несколько демоническую внешность. Впечатление усиливается черным цветом одежды со стоячим воротником. Шухаев создает обобщенный вид одежды, свойственной человеку его профессии, выводя однобортный приталенный сюртук (китель или пиджак) черного цвета, обшитые красной материей обшлага, стоячий воротник. Обязательным атрибутом являются эполеты, они присутствуют на всех явных портретах Германна.

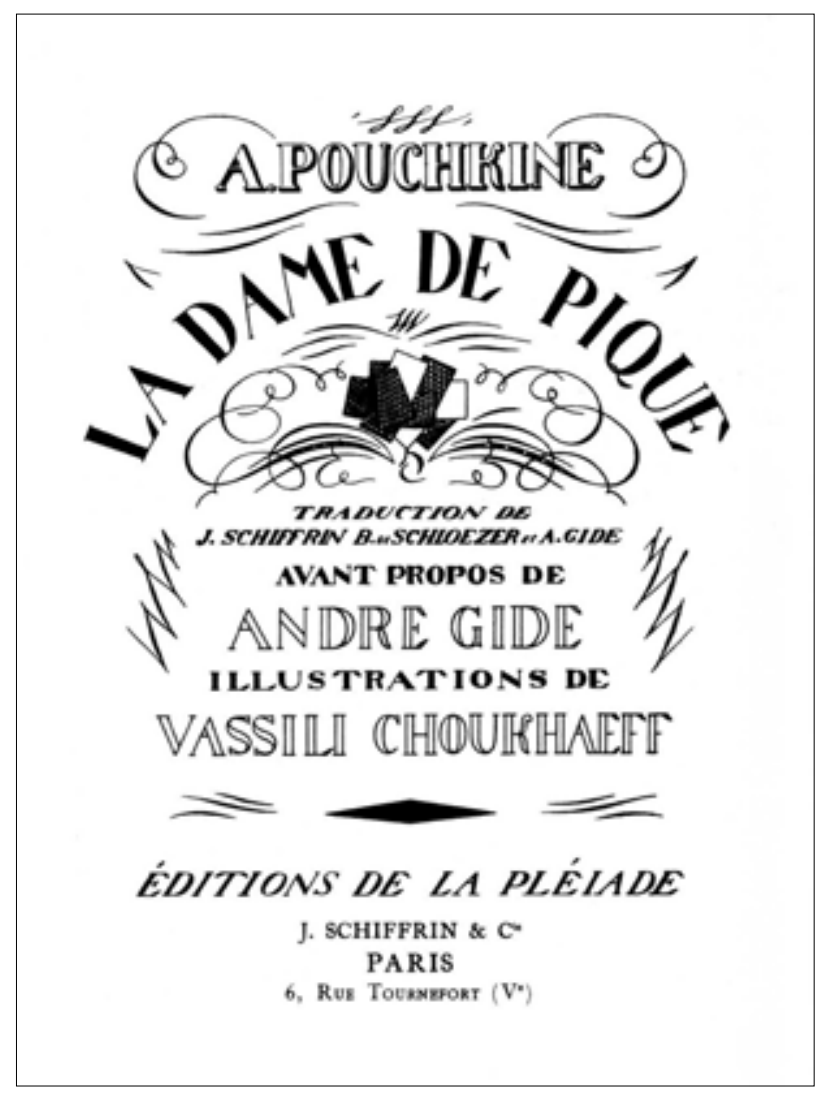

Титульный лист издания [6]

Некоторое расхождение в обрисовке головного убора Германна (похожего на кивер и подобие двууголки) позволяет сделать вывод, что речь идет о стремлении художника передать, как отмечает C.А. Мартьянова, намерение А.С. Пушкина отразить начавшееся «значимое для персонажной сферы русской литературы XIX века движение от типа к индивидуальности и личности» [8].

Поскольку А.С. Пушкин не акцентирует внимание на одежде Германна, В.И. Шухаев допускает вольность трактовки. Некоторая условность обусловливается также тем, что каждый новый император желал внести новшества в военный костюм, не говоря о том, что всякое военное подразделение стремилось выделиться отдельными атрибутами. Для нас является значимым вписанность портрета Германна в текстовые иллюстрации.

Отметим сцену, изображающую Германна на улице Петербурга. Художник тщательно воссоздает городской пейзаж (зимнюю улицу, Смольный собор, фасад дома графини). Вписанность героя в конкретный ландшафт и особая перспектива изображения зданий на заднем плане в соразмерности с фигурами героев восходит к традиции изображения на итальянском пейзаже, служившем для Шухаева своеобразным эталоном при создании перспективы. В то же время наблюдаем и атрибутику 


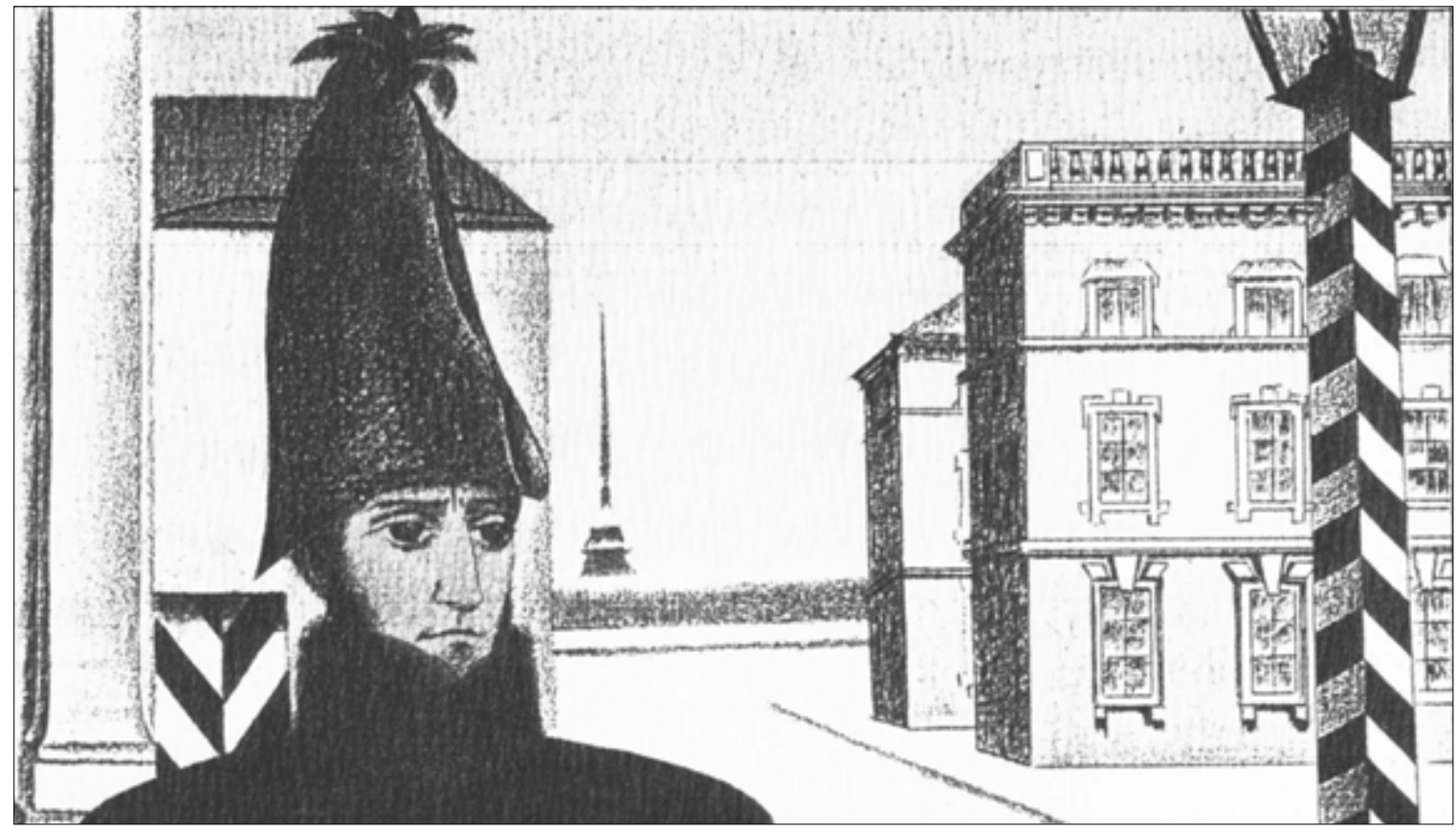

В.И. Шухаев. Германн на улице Петербурга

«петербургского текста», одним из ключевых символов которого становится шпиль. Действие повести происходит зимой. А.С. Пушкин в данном случае лаконичен: «Погода была ужасная: ветер выл, мокрый снег падал хлопьями; фонари светились тускло; улицы были пусты».

В словесном решении Шухаева важно подчеркнуть другое: симметрично расположенные с обеих сторон заставки опорные сооружения - колонна и шлагбаум. Они становятся символами города и обозначением границы, отделяющей разные миры героев. Природное время действия подчеркивается белым цветом.

Нарочито спокойный ритм заставочной иллюстрации второй главы резко контрастирует с заставкой третьей главы, изображающей встречу главных героев возле дома графини. Теперь в качестве фона использован оттенок коричневого цвета, рыжевато-коричневый. Пушкин сообщает: «В то самое время, как два лакея приподняли старуху и просунули в дверцы, Лизавета Ивановна у самого колеса увидела своего инженера; он схватил ее руку; она не могла опомниться от испугу, молодой человек исчез: письмо осталось в ее руке». Решение сюжетной ситуации несколько напоминает кинокадры, представлены крупный, средний и мелкий планы. Шухаев резко ограничивает поле зрения, показывая части кареты, колесо и заднюю часть; обрисована также фигура сопровождающего ее мужчины (кивер указывает на военного, что позволяет предположить присутствие Томского). Головные уборы тщательно выписаны, введены разновидности муж- ской военной формы (двууголка и кивер), у женщины - головной убор наподобие капора. В соответствии с модой мужчины носят бакенбарды.

Сосредоточение на отдельных деталях позволяет художнику передать динамику сюжета. Германн показан бегущим, Шухаев точно передает наклонное положение тела, вытянутая вперед рука подчеркивает движение. Черный плащ резко контрастирует с рукой в белой перчатке. Лиза, напротив, изображена подчеркнуто статично - стоит, полуобернувшись, и протягивает руку, чтобы взять адресованное ей письмо. На передний план также выведена ее рука в белой перчатке, за нее держится Германн. В центре, таким образом, оказываются две фигуры.

Пространственно-временные отношения подчеркивают градостроительные элементы, показаны постройки, характерные для времени действия повести. Кроме того, на левом краю рисунка вновь появляется черно-белый столб, выполняющий функцию ключевого слова и несущий в себе атрибутивное значение топоса. Использование контрастных частей рисунка или картины является отличительной особенностью Шухаева-художника.

А.С. Пушкин позволяет точно обозначить место действия, что служит основанием для организации текстового пространства иллюстрации: Германн очутился «в одной из главных улиц Петербурга, перед домом старинной архитектуры»; «он стоял у самого подъезда, закрыв лицо бобровым воротником: черные глаза его сверкали из-под шляпы».

Несколько иллюстраций Шухаев посвящает одной из ключевых сцен романа - ночной встрече 
Германна и графини. На первой, страничной, которая предваряет третью главу, изображен кульминационный момент. Германн целится в графиню из пистолета, она пытается заслониться рукой. Иллюстрация построена на контрасте черного и белого. Мы видим силуэт Германна, одетого в черный мундир, и белую фигуру графини в ночной сорочке и чепце, оттеняемую черной ширмой за ее спиной.

Ситуация соответствует описанию в повести: «Графиня сидела вся желтая, шевеля отвислыми губами, качаясь направо и налево. В мутных глазах ее изображалось совершенное отсутствие мысли; смотря на нее, можно было бы подумать, что качание страшной старухи происходило не от ее воли, но по действию скрытого гальванизма. Вдруг это мертвое лицо изменилось неизъяснимо. Губы перестали шевелиться, глаза оживились: перед графинею стоял незнакомый мужчина». В повести содержится указание на то, что Германн был одет в сюртук, так он и представлен художником. Здесь появляется первый полноценный портрет героя, он показан во весь рост.

Продолжение сюжетной ситуации и соответственно использование приема повтора наблюдаем в четвертой главе. В кресле изображена лежащая графиня, сзади, в глубине комнаты, стоит Германн с опущенным пистолетом в руке. В заставочной иллюстрации на сей раз доминирует портрет. Иллюстрация снова выстраивается на доминанте световых пятен, коричневато-черного и белого.

Перспектива едва намечена клетчатым рисунком пола, за спиной Германна - стул с овальной спинкой. И стул, и пол, и угол комнаты мы видим на следующем рисунке, который иллюстрирует рассказ Германна. Шухаев приглушает цветовую гамму, увеличивая контрастное изображение, строящееся на минимальном использовании цветов и позволяющее выделить фигуры действующих лиц.

Графиня лежит в кресле с высокой спинкой и подлокотниками, называемом «вольтеровским», на изображении появляется временная деталь действие повести разворачивается в XVIII веке. Художник точно следует за словами Пушкина: «В этом наряде, более свойственном ее старости, она казалась менее ужасна и безобразна». Халат графини неопределенного темного цвета. Видны морщины на лбу и шее, откинутая и заостренная челюсть свидетельствуют об отсутствии зубов. Обтянутое кожей лицо также свидетельствует о возрасте.

В глубине комнаты стоит Германн с пистолетом в руке. Еще дальше, у стены, виден стул, выведенный в предыдущей иллюстрации. На полу - тот же узор из квадратных клеток. В полутемной комнате белеет лишь чепец на голове графини. Неподвижность поз героев позволяет передать не только настроение Германна, но и ощущение непоправимости произошедшего; он слегка согнул ногу и как бы размышляет о дальнейших действиях.
Третий раз белый силуэт графини изображен в сцене видения. На полу комнаты Германна - тень от незанавешенного окна, воспроизводящая тот же узор из квадратных клеток. Из дверного проема в самой дальней от зрителя стене комнаты появляется белый силуэт графини (он фиксируется деталями, белым одеянием и чепцом). Вот-вот она вступит на призрачные квадраты на полу. Принцип зеркальности проявился и в позах героев, теперь на софе полулежит Германн. Он повернут в профиль, глаз увеличен, выражение лица символизирует испуг и удивление. Зеркальная ситуация усиливает восприятие.

Германн одет в черный мундир, нарисованный как одно пятно, отдельные детали - шарф и эполеты - воспринимаются как органические его составляющие. Художник третий раз повторяет ту же цветовую антитезу, но теперь она приобретает характер фантасмагории. Подобная условность изображения сохранится и в его творчестве в дальнейшем, будет использована и при иллюстрировании произведений Н.В. Гоголя, став особенностью идиостиля.

На противостоянии героев построена и сцена у гроба графини. На сей раз выделяется фигура Германна, выделяются нервно сжатые руки и выпученные глаза. Так обозначается состояние персонажа. А.С. Пушкин сообщает последовательно весь ход событий, когда Германн решил подойти, «приподнялся, бледен как сама покойница, взошел на ступени катафалка и наклонился...». Отчаяние сменяется выражениями ужаса, страничная иллюстрация передает неотвратимый трагический финал. Стремясь передать драматизм происходящего, Шухаев вводит иной взгляд Германна.

В то же время художник разрушает статику, выраженную Пушкиным в последовательном перечислении событий: «Гроб стоял на богатом катафалке под бархатным балдахином. Усопшая лежала в нем с руками, сложенными на груди, в кружевном чепце и в белом атласном платье. Кругом стояли ее домашние: слуги в черных кафтанах с гербовыми лентами на плече и со свечами в руках; родственники в глубоком трауре, - дети, внуки и правнуки».

Сохранив детали, хотя и не все (бархатный балдахин отсутствует), художник тщательно выписывает действующих лиц. На первый план выведены мужские фигуры, из которых прорисовано лицо только одного из них. На заднем плане виднеется фигура женщины, в испуге поднесшая руку к лицу, она и обозначает удивление от случившегося. Демонического облика фигура Германна поддерживает ирреальность происходящего, акцентируя внимание на визуальной составляющей.

Постановочный характер носит и постраничная иллюстрация к четвертой главе, на которой в статичных позах изображены Германн и Лиза- 
вета Ивановна. Шухаев представляет собственное прочтение повести, несколько отходя от деталей, присутствующих у А.С. Пушкина. Поддерживая принцип парного портретирования, художник располагает героев на одной плоскости. Лиза частично освободилась от бального наряда, больше похожа на куклу с аккуратно сложенными руками. Одежда Германна не меняется, о его состоянии говорят скрещенные руки, его образ романтический и отчасти демонический.

Прологом служат слова Томского: «Этот Германн... лицо истинно романическое: у него профиль Наполеона, а душа Мефистофеля. Я думаю, что на его совести по крайней мере три злодейства». Лиза дополняет эту характеристику: «Портрет, набросанный Томским, сходствовал с изображением, составленным ею самою, и, благодаря новейшим романам, это уже пошлое лицо пугало и пленяло ее воображение».

Шухаев усиливает соединение обыкновенности и героического позой и цветовым решением, контрастом между белым платьем героини и черным мундиром героя. Германн, как будто замерший в отчаянии, выделяется цветовым решением, видны бледное лицо и белые руки. Второстепенный персонаж повести дополняет характеристику другого героя: «Лизавета Ивановна погасила догорающую свечу: бледный свет озарил ее комнату. Она отерла заплаканные глаза и подняла их на Германна: он сидел на окошке, сложа руки и грозно нахмурясь. В этом положении удивительно напоминал он портрет Наполеона. Это сходство поразило даже Лизавету Ивановну». Художник сохранил позу героя, несколько изменив его местоположение.

Последовательное прочтение произведения А.С. Пушкина, несомненно, отразилось в иллюстративном пространстве повести. Художник практически создает свой вариант видения текста, акцентируя внимание на драматической составляющей произведения. Он использует визуальность изображения А.С. Пушкина, чтобы вывести свою читательскую концепцию прочтения «Пиковой дамы».

Иллюстративная серия, посвященная «Пиковой даме», задумана и выполнена В.И. Шухаевым как своеобразный синтез опыта, накопленного его предшественниками, и собственного прочтения текста. «Художник использует те же три изобразительные линии, что и А.Н. Бенуа, но воплощает их совершенно по-другому» $[2$, с. 6$]$.

Мы показали основные приемы работы Шухаева как художника-иллюстратора. Он проявил себя и продолжателем традиций, и новатором. Н.Э. Радлов, видевший его графические работы художни- ка на выставке, открывшейся в Ленинграде осенью 1936 г., охарактеризовал их следующим образом: «Мастерство Шухаева - прекрасный инструмент, отточенный большим опытом, превосходной школой» $[11$, с. 6].

Как иллюстратор В.И. Шухаев не только выдержал конкуренцию с французскими художниками, но и внес собственные находки. Он предложил принцип монтажа в графике, разработал новую методику рисунков тушью, кроме того, создал единый художественный комплекс книги от обложки до последней концовки. В.И. Шухаев доказал, что оформление, полностью адекватное авторскому замыслу, возможно лишь при условии, что художник создает все части образа книги, подчиняя их единой творческой концепции.

\section{Список источников}

1. Мямлин И.Г. Василий Иванович Шухаев. Ленинград : Художник РСФСР, 1972. 173 с.

2. Эйзарбашвили Н.А. В.И. Шухаев. Москва : Галарт, 2012. 360 c.

3. Сеславинский М. Россия - Франция: полузабытые страницы культурного сотрудничества [Электронный ресурc]. URL: http://seslavinsky.ru/articles/ rossiya-frantsiya-poluzabytye-stranitsy-kulturnogosotrudnichestva/ (дата обращения: 01.03.2018).

4. Ткаченко Н.И. Книга-художника - феномен малого искусства // Обсерватория культуры. 2011. № 3. C. $118-122$.

5. Фещенко В. Автоэкфрасис в тексте художника: лингвоэстетический эксперимент В. Кандинского // «Невыразимое выразимое»: экфрасис и проблемы репрезентации визуального в художественном тексте : сб. статей / сост. и науч. ред. Д.В. Токарева. Москва : Новое литературное обозрение, 2013. С. 164-181.

6. Pouchkine A. La dame de pique / avant propos de A. Gide ; illustrations couleurs de V. Choukhaeff. Paris : La Pléiade Schiffrin \& $C^{\mathrm{ie},} 1923$.

7. Pouchkine A. Boris Goudunov. Paris : La Pleiade Schiffrin $\& \mathrm{C}^{\mathrm{ie}}, 1925$.

8. Мартьянова С.А. Образ Германна в повести Пушкина А.С. «Пиковая дама»: национальное и общечеловеческое // Вестник Нижегородского университета им. Н.И. Лобачевского. 2014. № 2. С. 53-57.

9. Лихачёв Д.С. Письма о добром и прекрасном / сост. и общ. ред. Г.А. Дубровской. Москва : Дет. лит., 1989. $238 \mathrm{c}$.

10. Шухаев В.И. Воспоминания // Государственный русский музей. Отдел письменных источников. Ф. 154. Ед. хр. 205. Л. 56.

11. Радлов Н.Э. Выставка произведений. Каталог. Москва : Моск. отд. Союза художников РСФСР, 1961. 25 с. 


\section{Artist's Visual Representation of the Portrait of Hermann in A.S. Pushkin's “Queen of Spades"}

\section{Vera F. Kapitsa}

Gorky Institute of World Literature, 25a, Povarskaya Str., Moscow, 121069, Russia

E-mail: kapicavera@mail.ru

\begin{abstract}
Among the Russian emigrants of the 1920s1930s, there was a specific community of the representatives of artistic world who supported the tendency to preserve the national culture and at the same time sought to bring it into the world context, taking into account the creative searches conducted at that time. One of those representatives of emigration was the painter, graphic and scenographer V.I. Shukhaev (1887-1973). It was in France where he developed the conception of artist's books that were perceived as special pieces of art, in which all elements of the book had their meaning. Two significant works of V.I. Shukhaev in the field of book graphics are associated with the name of A.S. Pushkin: those are the illustrations to the story "Queen of Spades" and the tragedy "Boris Godunov".

This article uses the French edition of 1923 of A.S. Pushkin's "Queen of Spades" as a material for research. This edition was chosen because in there V.I. Shukhaev not only performed the illustrations, but also presented his own original vision of the work. He clarified and specified different individual features of the narrative construction of the story, using his inherent artistic language.

The subject of this specific study is the originality of V.I. Shukhaev's vision of the story's main character - Hermann, the peculiarities of his portrait characteristics, and the methods of its organization. Consistent reading of the work is, undoubtedly, reflected in the illustrative space of the story. The artist almost creates his own perspective of the text vision, focusing on the dramatic component of the work. He uses the visuality of Pushkin's image to bring out his own reader's conception of reading the "Queen of Spades". The article demonstrates basic working methods of the artist, who proved to be the successor of traditions and the innovator.
\end{abstract}

As an illustrator, V.I. Shukhaev not only withstood the competition with French artists, but also made his own findings: he proposed the principle of installation in graphics, developed a new method of ink drawings, created a single artistic complex of the book from its cover to the last ending. V.I. Shukhaev proved that the design fully adequate to the author's idea is possible only if the artist cre- ates all the parts of the book's image, subordinating them to a single creative conception.

Key words: Russian emigration, artist's book, A.S. Pushkin, V.I. Shukhaev, character, visual representation.

Citation: Kapitsa V.F. Artist's Visual Representation of the Portrait of Hermann in A.S. Pushkin's “Queen of Spades”, Observatory of Culture, 2018, vol. 15, no. 2, pp. 214-221. DOI: 10.25281/2072-3156-2018-15-2-214-221.

\section{References}

1. Myamlin I.G. Vasily Ivanovich Shukhaev. Leningrad, Khudozhnik RSFSR Publ., 1972, 173 p.

2. Eizarbashvili N.A. V.I. Shukhaev. Moscow, Galart Publ., 2012, 360 p.

3. Seslavinsky M. Rossiya - Frantsiya: poluzabytye stranitsy kul'turnogo sotrudnichestva [Russia - France: The Half-Forgotten Pages of Cultural Cooperation]. Available at: http://seslavinsky.ru/articles/rossiya-frantsiyapoluzabytye-stranitsy-kulturnogo-sotrudnichestva/ (accessed 01.03.2018).

4. Tkachenko N.I. Artist's Book - A Phenomenon of Small Art, Observatoriya kul'tury [Observatory of Culture], 2011, no. 3, pp. 118-122 (in Russ.).

5. Feshchenko V. Autoekphrasis in the Artist's Text: V. Kandinsky's Linguoaesthetic Experiment, "Nevyrazimo vyrazimoe”: ekfrasis i problemy reprezentatsii vizual'nogo $v$ khudozhestvennom tekste: sb. statei ["The Inexpressibly Expressible": Ekphrasis and the Issues of Representing the Visual in Artistic Text: collected articles]. Moscow, Novoe Literaturnoe Obozrenie Publ., 2013, pp. 164-181 (in Russ.).

6. Pouchkine A. La dame de pique. Paris, La Pléiade Schiffrin \& Cie Publ., 1923.

7. Pouchkine A. Boris Goudunov. Paris, La Pleiade Schiffrin \& Cie Publ., 1925.

8. Martyanova S.A. Hermann in Pushkin's Story "Queen of Spades": The National and Universal, Vestnik Nizhegorodskogo universiteta im. N.I. Lobachevskogo [Bulletin of the Lobachevsky University of Nizhny Novgorod], 2014, no. 2, pp. 53-57 (in Russ.).

9. Likhachov D.S. Pis'ma o dobrom i prekrasnom [Letters about the Kind and Beautiful]. Moscow, Detskaya Literatura Publ., 1989, 238 p.

10. Shukhaev V.I. Memories, Gosudarstvennyi russkii muzei. Otdel pis'mennykh istochnikov [State Russian Museum. The Department of Written Sources], coll. 154, item 205, p. 56 (in Russ.).

11. Radlov N.E. Vystavka proizvedenii. Katalog [Exhibition of Works. Catalogue]. Moscow, Moskovskoe Otdelenie Soyuza Khudozhnikov RSFSR Publ., 1961, 25 p. 